\title{
Periovulatory changes in hypothalamic and pituitary monoamines following GnRH analogue treatment in the catfish Heteropneustes fossilis: a study correlating changes in plasma hormone profiles
}

\author{
K P Joy, B Senthilkumaran and C C Sudhakumari \\ Department of Zoology, Banaras Hindu University, Varanasi-221 005, India \\ (Requests for offprints should be addressed to K P Joy)
}

\begin{abstract}
In Heteropneustes fossilis, administration of a single dose $(0 \cdot 15 \mu \mathrm{g} / \mathrm{g}$ body weight, i.p. $)$ of $\left[\mathrm{D}-\mathrm{Ala}^{6}, \mathrm{Gly}^{10}\right]-$ gonadotrophin-releasing hormone analogue (GnRHa) induced ovulation (in 35 of 35 fish) when mild-stripped at $16 \mathrm{~h}$. Plasma gonadotrophin II (GTH II) levels showed a highly significant increase at 2, 4, 8, 12 and $16 \mathrm{~h}$ with the peak at $8 \mathrm{~h}$. Plasma cortisol, progesterone and testosterone showed significant elevations at 2, 4, 8 and $12 \mathrm{~h}$ with peaks at $8 \mathrm{~h}$ (cortisol and testosterone) and $4 \mathrm{~h}$ (progesterone). The levels declined to control values at 16 and $48 \mathrm{~h}$ except that of testosterone which decreased even further. In contrast, plasma levels of oestradiol-17 $\beta$ decreased significantly at 2, 4, 8 and $12 \mathrm{~h}$, with the lowest value at $8 \mathrm{~h}$, but increased at 16 and $18 \mathrm{~h}$. The contents of hypothalamic and pituitary serotonin and noradrenaline increased at $8 \mathrm{~h}$, coinciding with the peak GTH II rise, and decreased at $16 \mathrm{~h}$. In contrast, dopamine content
\end{abstract}

declined at $8 \mathrm{~h}$ in both the hypothalamus and pituitary, but increased at $16 \mathrm{~h}$ only in the hypothalamus. The hypothalamic adrenaline level decreased at $8 \mathrm{~h}$ but increased significantly at $16 \mathrm{~h}$. Hypothalamic levels of monoamine oxidase, catechol O-methyltransferase and dopamine $\beta$-hydroxylase were elevated significantly at $8 \mathrm{~h}$; the dopamine $\beta$-hydroxylase activity decreased at $16 \mathrm{~h}$. Phenylethanolamine $N$-methyltransferase activity was elevated only at $16 \mathrm{~h}$, coinciding with the rise in adrenaline content. It is inferred that the preovulatory decrease in dopamine content concomitant with rises in serotonin and noradrenaline levels, triggered by the low titre of oestradiol, might have potentiated the $\mathrm{GnRHa} / \mathrm{GnRH}$ (endogenous)-induced release of GTH II for a prolonged period.

Journal of Endocrinology (1998) 156, 365-372

\section{Introduction}

In teleosts, hypothalamic monoamines (dopamine (DA), noradrenaline (NA) and serotonin (5-HT)) exert a stimulatory or inhibitory effect on gonadotrophin II (GTH II) secretion (Peter et al. 1991). DA is the most dominant inhibitory mechanism that inhibits basal or gonadotrophinreleasing hormone $(\mathrm{GnRH})$-induced GTH II release in several species including the catfish (Chang \& Peter 1983, de Leeuw et al. 1987, Goos et al. 1987, Trudeau \& Peter 1995, Senthilkumaran \& Joy 1996). NA and 5-HT have been shown to facilitate GTH II release (Somoza \& Peter 1991, Khan \& Thomas 1992, Yu \& Peter 1992, Trudeau \& Peter 1995, Senthilkumaran \& Joy 1996). The use of $\mathrm{GnRH}$ and its superactive analogues alone or in combination with DA receptor antagonists has become the basis of a simple and reliable method of induced breeding in teleosts (Peter et al. 1991, Yaron 1995). However, apparent seasonal or species variations with regard to dosage of GnRH, degree of DA inhibition of GTH II release, latency period of spawning response, etc. have

been found in spawning trials (Peter et al. 1991, Yaron 1995, Tharakan \& Joy 1996). Tharakan \& Joy (1996) have shown that a single injection of $0.5 \mu \mathrm{g} / \mathrm{g}$ body weight $\left[\mathrm{D}-\mathrm{Ala}^{6}-\mathrm{Gly}^{10}\right]$-gonadotrophin-releasing hormone analogue $(\mathrm{GnRHa})$ could induce ovulation in the catfish Heteropneustes fossilis without the use of a DA antagonist. In such instances, the question arises how the exogenously administered GnRHa overcomes the endogenous DA inhibition of the preovulatory GTH II surge and whether the treatment triggers endogenous mechanism(s) controlling GTH II secretion as well. In the present study, we report the periovulatory changes in hypothalamic and pituitary monoamine metabolism in catfish induced to ovulate by GnRHa treatment, and correlate them with plasma levels of GTH II, sex steroids and cortisol.

\section{Materials and Methods}

Adult mature female catfish weighing 90-100 g were purchased from local fish markets in and around Varanasi 
in the first week of July (early spawning phase). They were checked for spontaneous ovulation. About 110 females were injected with $0.15 \mu \mathrm{g} / \mathrm{g}$ body weight GnRHa (Sigma, St Louis, MO, USA) i.p. in the evening (18 h). This dose was selected because, in pilot dose-determination studies, it could induce a high rate of ovulation in this species. As controls, 110 fish were given $0.1 \mathrm{ml}$ vehicle $(0 \cdot 7 \% \mathrm{NaCl}$ containing $0 \cdot 25 \% \mathrm{BSA}$, fraction V; Sigma). Fish in the GnRHa and control groups were divided into seven batches of five and three batches of 25 each. The seven batches of fish from treated and control groups were bled at $0,2,4,8,12,16$ or $48 \mathrm{~h}$. Each batch of fish was used only once for blood collection to avoid stress. Blood was drawn from the caudal vein using a heparinized syringe with a 22 -gauge needle. Plasma was separated by centrifuging at $800 \mathrm{~g}$ for $20 \mathrm{~min}$ at $4{ }^{\circ} \mathrm{C}$. They were checked for ovulation $16 \mathrm{~h}$ after injection by mild hand-stripping. Fish that yielded a copious stream of translucent green-brown eggs were rated as having ovulated and scored individually. Twenty-five fish from each of the remaining batches were killed at 0,8 and $16 \mathrm{~h}$ (after stripping of eggs) for the estimation of monoamines and related enzymes. Brains were quickly dissected out on ice and the hypothalami were separated, as described previously (Senthilkumaran \& Joy 1993), and stored at $-20{ }^{\circ} \mathrm{C}$ for $2-3$ days. Pituitaries were similarly removed and stored at $-20^{\circ} \mathrm{C}$ for estimation of amine contents. Blood had not been previously withdrawn from these fish to avoid stress.

\section{RIA of GTH II}

Plasma GTH II levels were estimated by a heterologous assay (Senthilkumaran \& Joy 1994) following the procedure of Goos et al. (1986). Intra- and interassay coefficients of variation were 5.2 and $8.9 \%$ respectively. The minimum sensitivity limit of the assay was $800 \mathrm{pg} / \mathrm{ml}$. Other details of the assay were as described previously. Since only a single gonadotrophin corresponding to GTH II of other teleosts is present in catfish (Koide et al. 1992), we use GTH II to describe the GTH measured in this study.

\section{RIA of testosterone, oestradiol-17 $\beta\left(\mathrm{OE}_{2}\right)$ and progesterone}

Plasma levels of steroid hormones were measured by the RIA method of Abraham (1974). Details of testosterone and $\mathrm{OE}_{2}$ assays were as described previously (Senthilkumaran \& Joy 1994). The coefficients of intraand interassay variation for the $\mathrm{OE}_{2}$ assay were 1.5 and $2.9 \%$ respectively. The progesterone assay was performed using $\left[1,2,6,7-{ }^{3} \mathrm{H}\right]$ progesterone (specific radioactivity $85 \mathrm{Ci} / \mathrm{mmol}$; ICN, CA, USA) and its antiserum (ICN). The assay procedure was similar to that of $\mathrm{OE}_{2}$, as described previously (Senthilkumaran \& Joy 1994). The cross-reactivity of the antibody was $3 \%$ with $17 \alpha$-hydroxyprogesterone and $1 \%$ with $17 \alpha, 20 \beta-$ dihydroxyprogesterone $(17 \alpha, 20 \beta-\mathrm{P})$. The sensitivity limit of the assay was $10 \mathrm{pg} / \mathrm{ml}$. The intra- and interassay coefficients of variation were 3.5 and $4.7 \%$ respectively.

\section{Enzyme immunoassay (EIA) of plasma cortisol}

Plasma cortisol was estimated by the double-antibody EIA method of Shrivastav et al. (1988). The details are as follows. Cortisol EIA kit was a gift from Dr G L Kumari, NIHFW, New Delhi, India. Cortisol-21-hemisuccinate was coupled with penicillinase by the carbodi-imide method of Mattox et al. (1979), as described by Shrivastav et al. (1988). Different concentrations of the standard (10-2000 pg/100 $\mu \mathrm{l}$ in $10 \mathrm{mM}$ sodium phosphate buffer $(\mathrm{pH} 7 \cdot 0)$ containing $154 \mathrm{nM} \mathrm{NaCl}(\mathrm{PBS}), 15 \mathrm{nM}$ sodium azide and $1 \mathrm{~g} / 1$ gelatin or BSA (assay buffer)) and $10 \mu \mathrm{l}$ of the reconstituted plasma (extracted with ethanol, dried and reconstituted in PBS) were assayed in duplicate. Cortisol antibody $(100 \mu \mathrm{l}$ at 1:4000 dilution in the assay buffer containing normal rabbit serum (1:500 dilution)) and $100 \mu \mathrm{l}$ of the enzyme conjugate (1:600 dilution) were mixed and incubated at $4{ }^{\circ} \mathrm{C}$ overnight. Anti-rabbit IgG (1:80 dilution in $200 \mu \mathrm{l}$ of assay buffer) was added and incubated for $2 \mathrm{~h}$ at $37^{\circ} \mathrm{C}$. After the incubation, $30 \mu \mathrm{l}$ celite solution ( $1 \mathrm{~g} / 1$ in assay buffer) and $1 \mathrm{ml}$ PBS were added to the tubes. They were centrifuged at $800 \boldsymbol{g}$ for $10 \mathrm{~min}$ and the pellets were washed twice with $2 \mathrm{ml}$ PBS. The process was repeated and the supernatant discarded. The sides of the tubes were wiped off; $200 \mu \mathrm{l}$ freshly prepared $1 \mathrm{M}$ penicillin $\mathrm{V}$ (substrate) in PBS was then added to each tube and the mixture vortex-mixed thoroughly. They were again incubated at $37^{\circ} \mathrm{C}$ for $1 \mathrm{~h}$. At the end of the incubation, $2 \mathrm{ml}$ starch-iodine solution (prepared by mixing with constant stirring $0.25 \mathrm{ml} 18 \mathrm{nM}$ iodine in $3.325 \mathrm{M}$ potassium iodide in distilled water with $190 \mathrm{ml} 0 \cdot 2 \mathrm{M}$ PBS, containing $3 \mathrm{ml} 20 \mathrm{~g} / 1$ hydrolysed starch) were added to each tube and the enzymatic reaction was stopped within $10 \mathrm{~min}$ by adding $1 \mathrm{ml} 5 \mathrm{M}$ $\mathrm{HCl}$. The end point of the reaction was the appearance of blue colour which was read at $620 \mathrm{~nm}$ in a Kontron spectrophotometer. The sensitivity limit of the assay was $10 \mathrm{pg} / \mathrm{ml}$. In our assay system, the cross-reactivity of the antibody was $<0.7 \%$ for progesterone, $5 \%$ for $17 \alpha-$ hydroxyprogesterone, $22 \%$ for cortisone, $3 \%$ for corticosterone, $<0.5 \%$ for testosterone and $<0.5 \%$ for $\mathrm{OE}_{2}$. The intra- and interassay coefficients of variation were $7 \cdot 7$ and $9 \cdot 3 \%$ respectively. In order to evaluate further the specificity of the assay, plasma from a group of five fish given metopirone $(2 \mu \mathrm{g} / \mathrm{g}$ body weight i.p. for 7 days) was used for the cortisol assay. The control fish received $0 \cdot 6 \% \mathrm{NaCl}$. The treatment caused a significant reduction of cortisol (about 56\%) when compared with that of the control.

\section{Estimation of hypothalamic and pituitary monoamines}

5-HT was assayed by the spectrofluorimetric method of Snyder et al. (1965). For assay of pituitary 5-HT, three 
pituitaries were pooled to make a sample. Catecholamine contents were measured radioenzymatically by the method of Ben-Jonathan \& Porter (1976) as modified by them later (1981, personal communication). The details of both the assays including validation were explained previously (Senthilkumaran \& Joy 1994, 1995). For assay of catecholamines in the pituitary, two pituitaries were pooled to make a sample.

Estimation of monoamine oxidase (MAO), catechol O-methyltransferase (COMT), phenylethanolamine $\mathrm{N}$-methyltransferase (PNMT) and dopamine $\beta$-hydroxylase (DBH)

Hypothalamic MAO, COMT and PNMT were measured by the radioisotopic method of Parvez \& Parvez (1973). DBH was assayed by the coupled radiometric procedure of Coyle \& Axelrod (1972). The details of these assays including validation were described previously (Senthilkumaran \& Joy 1994, 1995).

\section{Statistical Analysis}

All data are expressed as mean \pm s.E.M. The data for monoamines and related enzymes in the GnRHa and control groups were tested for significance by Student's $t$-test. The data for plasma hormone levels were analysed by a two-way ANOVA followed by Newman-Keuls' multiple range test.

\section{Results}

\section{Ovulation}

Of 35 fish checked for ovulation in the GnRHa group, all ovulated upon mild stripping at $16 \mathrm{~h}$. Even handling and holding the fish $12 \mathrm{~h}$ after the GnRHa injection led to extrusion of eggs from the ovipore. No fish in the control group ovulated even after hard stripping.

\section{Changes in plasma GTH II and steroid hormone levels (Fig. 1)}

Plasma GTH II (Fig. 1A) showed a highly significant elevation at all durations up to $16 \mathrm{~h}$ with the peak at $8 \mathrm{~h}$ (Newman-Keuls' test, $P<0 \cdot 05)$. The GTH II level was low at $48 \mathrm{~h}$ similar to that of the control group. A two-way ANOVA of the data demonstrated a highly significant effect of GnRHa treatment $(F=31187 \cdot 6, P<0 \cdot 001)$, duration $(F=3095 \cdot 3, P<0 \cdot 001)$ and interaction between these two factors $(F=3059, P<0 \cdot 001)$. Cortisol levels (Fig. 1B) were significantly increased at $2,4,8$ and $12 \mathrm{~h}$ of the GnRHa treatment with maximum elevation at $8 \mathrm{~h}$, and declined significantly at 16 and $48 \mathrm{~h}$ (Newman-Keuls' test, $P<0 \cdot 05)$. A two-way ANOVA of the data showed a significant effect of the treatment $(F=100 \cdot 8, P<0 \cdot 001)$, duration $(F=23 \cdot 8, \quad P<0 \cdot 001)$ and interaction between these two factors $(F=13 \cdot 5, P<0 \cdot 001)$. According to the Newman-Keuls' analysis, the levels at 2, 4 and $12 \mathrm{~h}$ did not vary significantly among themselves in the GnRHa group. Plasma progesterone and testosterone levels (Figs 1C and E) were elevated significantly after the GnRHa treatment at 2, 4, 8 and $12 \mathrm{~h}$ with the peak increases at 4 and $8 \mathrm{~h}$ respectively. The testosterone level declined significantly at 16 and $48 \mathrm{~h}$ (Newman-Keuls' test, $P<0 \cdot 05)$. A two-way ANOVA of the data showed a significant effect of the treatment (testosterone, $F=7687 \cdot 4$, $P<0 \cdot 001$; progesterone, $F=3578 \cdot 6, P<0 \cdot 001)$, duration (testosterone, $F=1268.5, \quad P<0 \cdot 001 ;$ progesterone, $F=$ 1565.3, $P<0 \cdot 001)$ and interaction between these two factors (testosterone, $F=3787 \cdot 9, P<0 \cdot 001$; progesterone, $F=1061 \cdot 7, \quad P<0 \cdot 001$ ). Plasma $\mathrm{OE}_{2}$ levels (Fig. 1D) declined significantly in the GnRHa groups at 2, 4, 8 and $12 \mathrm{~h}$ with the greatest reduction at $8 \mathrm{~h}$ (Newman-Keuls' test, $P<0 \cdot 05)$. However, a sharp and significant increase was noted at 16 and $48 \mathrm{~h}$ (Newman-Keuls' test, $P<0 \cdot 01$ ). A two-way ANOVA of the data showed a significant effect of the treatment $(F=1467 \cdot 3, \quad P<0 \cdot 001)$, duration $(F=1294 \cdot 4, P<0 \cdot 001)$ and interaction between these two factors $(F=1221 \cdot 1, P<0 \cdot 001)$.

Changes in hypothalamic and pituitary monoamine contents (Figs 2 and 3)

5 -HT contents in the hypothalamus and pituitary were elevated significantly at $8 \mathrm{~h}(P<0.01 ; P<0.001)$ and declined to control levels $16 \mathrm{~h}$ after the GnRHa administration. The NA contents also increased in both $(P<0 \cdot 01)$ at $8 \mathrm{~h}$. In the hypothalamus, the NA content at $16 \mathrm{~h}$ was significantly lower than the control level $(P<0 \cdot 001)$. The DA content showed a significant reduction at $8 \mathrm{~h}$ in both the hypothalamus and pituitary $(P<0 \cdot 01)$. At $16 \mathrm{~h}$ the hypothalamic DA content showed a significant increase $(P<0 \cdot 01)$ but the pituitary content was significantly lower than the control group $(P<0 \cdot 01)$. The concentration of hypothalamic adrenaline, on the other hand, did not differ significantly at $8 \mathrm{~h}$ but registered a significant rise at $16 \mathrm{~h}$ $(P<0 \cdot 01)$. In the pituitary, adrenaline was not detectable.

\section{Changes in hypothalamic MAO, COMT, PNMT and DBH activities (Fig. 4)}

In the GnRHa group, activities of MAO, COMT and DBH were significantly elevated $(P<0 \cdot 05, \quad P<0 \cdot 001$, Student's $t$-test) at $8 \mathrm{~h}$ and declined to control levels at $16 \mathrm{~h}$, except DBH activity which was decreased below the control value $(P<0 \cdot 001)$. Conversely, hypothalamic PNMT activity did not vary significantly at $8 \mathrm{~h}$ but increased at $16 \mathrm{~h}$ after the treatment $(P<0 \cdot 05)$. 

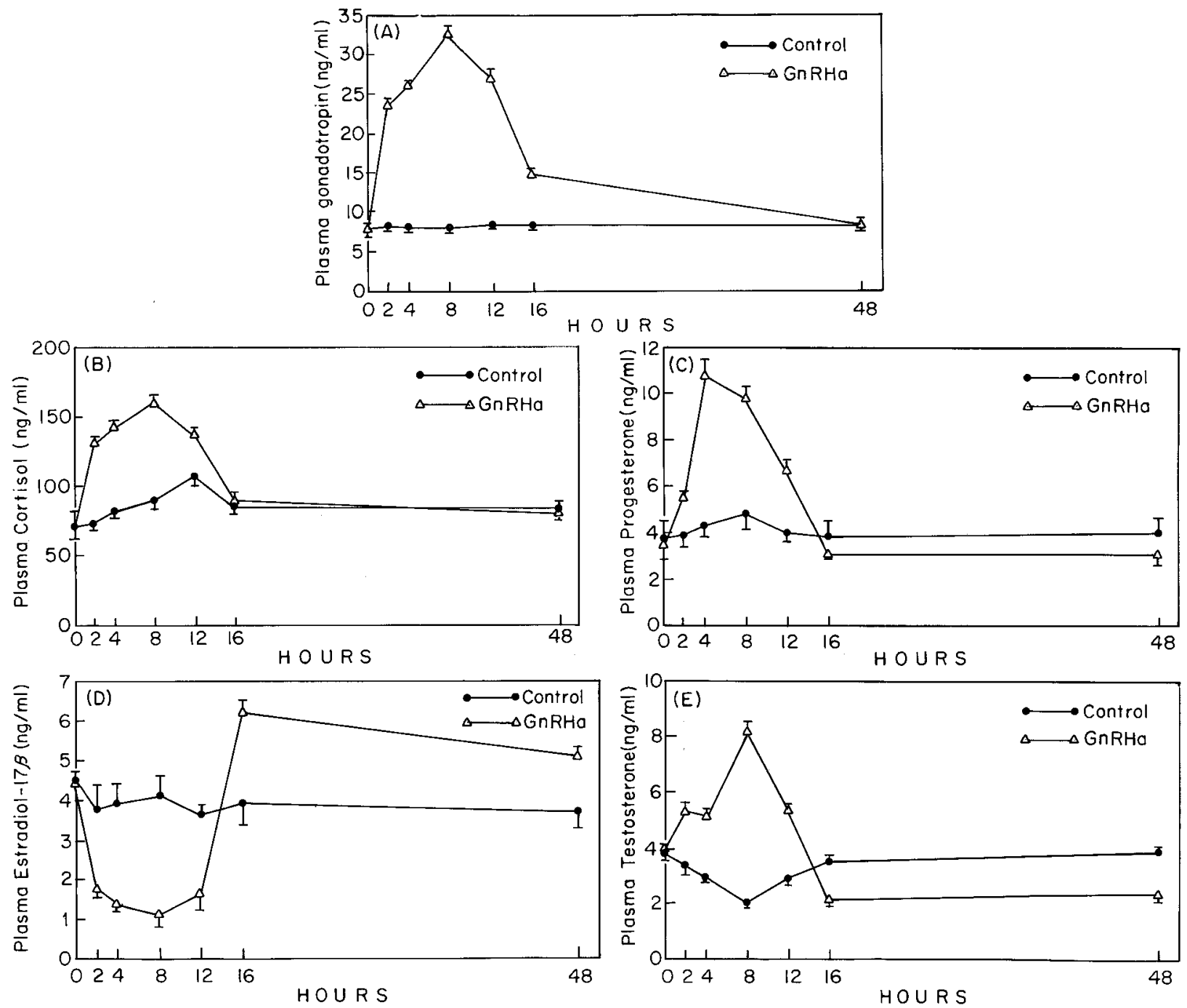

Figure 1 Periovulatory effects of a single injection of a mammalian GnRHa (0.15 $\mu \mathrm{g} / \mathrm{g}$ body weight) on plasma levels of gonadotrophin $(A)$, cortisol (B), progesterone (C), oestradiol-17 $(\mathrm{D})$ and testosterone (E) in the catfish Heteropneustes fossilis (means \pm S.E.M.; $n=5$; two-way ANOVA-Newman-Keuls' test).

\section{Discussion}

The present data show that a single injection of $0 \cdot 15 \mu \mathrm{g} / \mathrm{g}$ body weight of GnRHa can cause a very high rate of ovulation in the catfish after a latent period of $16 \mathrm{~h}$. The injected dose was only three times higher than that used normally with a DA antagonist to induce ovulation in catfish species (de Leeuw et al. 1985, Goos et al. 1987, Manickam \& Joy 1989, Tharakan \& Joy 1996). The GnRHa treatment resulted in a sustained and significant increase in plasma GTH II for $16 \mathrm{~h}$ with the peak at $8 \mathrm{~h}$. The prolonged action of GnRH analogues has usually been attributed to their long half-life and increased receptor affinity and/or occupancy (Van der Kraak et al. 1983).
However, the roles of other factors such as changes in endogenous neuroendocrine mechanisms have not been examined in such studies. It has been shown that DA is a GTH II-release inhibitor, but its effect varies considerably among species: strong, moderate or no effect (Peter et al. 1991, Yaron 1995). In H. fossilis, hypothalamic DA content and turnover have been reported to be lowest in the spawning phase, implying a toning down of the DA-inhibitory mechanism at this period (Senthilkumaran \& Joy 1995, control data). Nevertheless, spontaneous spawning does not occur in the catfish, which means that the residual DA activity seems to prevent the GTH II surge and spawning. During the GnRHa-induced ovulation, profound changes occurred in both hypothalamic 


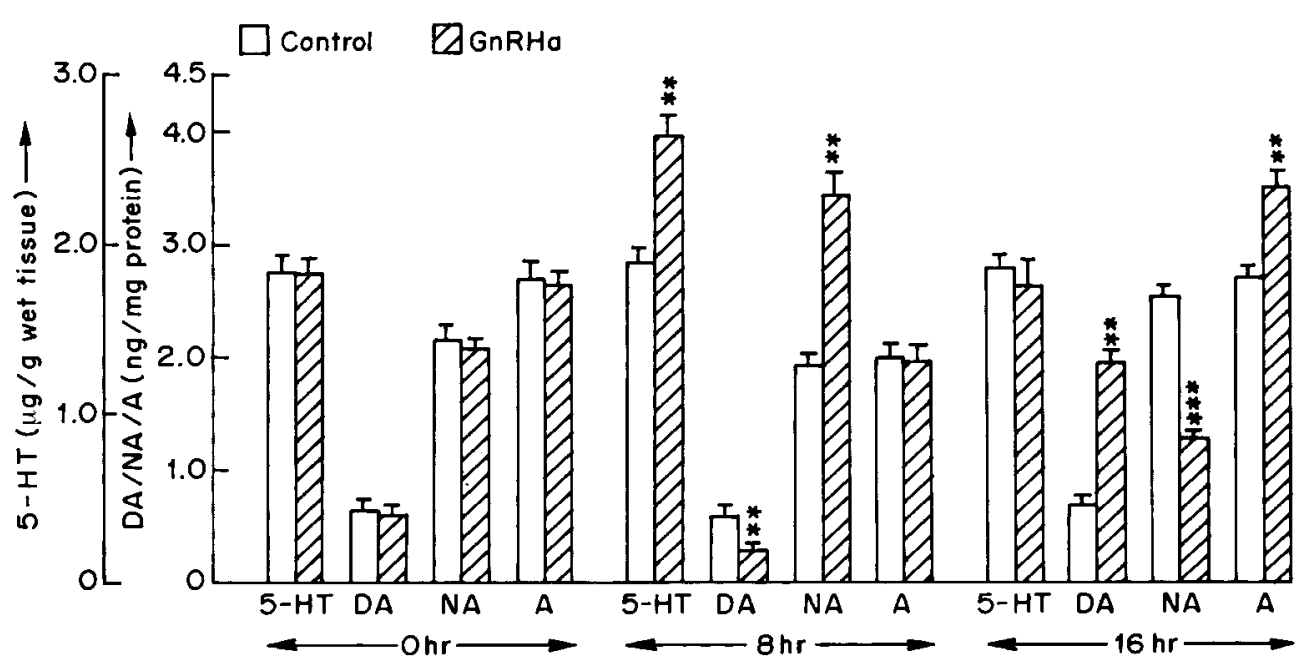

Figure 2 Periovulatory effects of a single injection of GnRHa on hypothalamic 5-HT, DA, NA and adrenaline (A) contents in the catfish Heteropneustes fossilis (means \pm S.E.M.; $n=5$ ). Comparisons with respective vehicle control: ${ }^{*} P<0 \cdot 01,{ }^{* * *} P<0 \cdot 001$; Student's t-test.

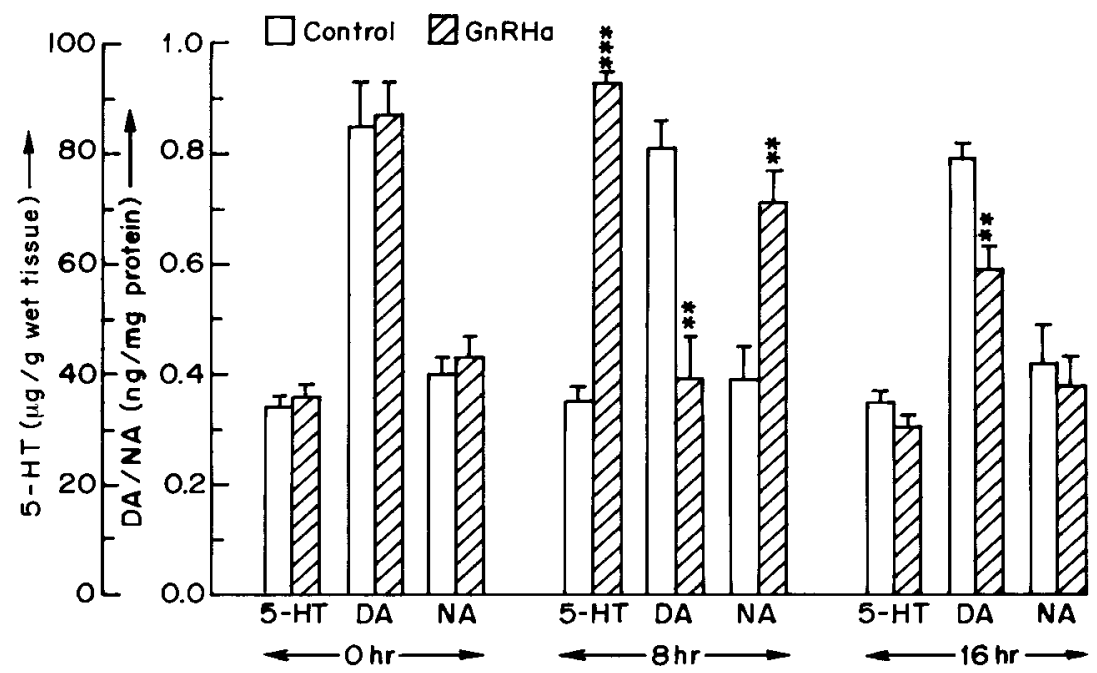

Figure 3 Periovulatory effects of a single injection of GnRHa on pituitary levels of 5-HT, $\mathrm{DA}$ and NA (means \pm S.E.M.; $n=5$ ). Comparisons with respective vehicle control groups:

${ }^{* *} P<0 \cdot 01,{ }^{* * *} P<0 \cdot 001 ;$ Student's $t$-test.

and pituitary monoamine metabolism. These changes were (1) depression of DA content at $8 \mathrm{~h}$ with concurrent elevation of 5-HT and NA contents, (2) increase in DA and decrease in NA contents at $16 \mathrm{~h}$ after extrusion of eggs, and (3) decrease in adrenaline at $8 \mathrm{~h}$ and subsequent increase at $16 \mathrm{~h}$. Although turnover of the amines was not examined in this study, the time-course changes in the activities of related enzymes in the hypothalamus could be a pointer to the nature of the events. The decrease in the DA content with a simultaneous increase in NA and $\mathrm{DBH}$ at $8 \mathrm{~h}$ clearly indicate increased conversion of DA into NA, as evident from increased DBH activity. The decrease in the NA content at $16 \mathrm{~h}$ might be due to decreased DA conversion, since DBH activity was lowered, or increased conversion of NA into adrenaline, since PNMT activity was elevated at this time point. The increased 5-HT content might be due to its increased synthesis. The elevated activity of the MA-degrading enzymes, MAO and COMT, at $8 \mathrm{~h}$ suggests increased degradation of the amines (increased neuronal activity). Thus, coincident with the GTH II surge at $8 \mathrm{~h}$, there was a depression of the inhibitory DA mechanism and stimulation of the NA and 5-HT mechanisms, a combination found to favour GTH II secretion (Senthilkumaran \& Joy 1996). The present study also reports the changes in pituitary amine contents in this species, which were 


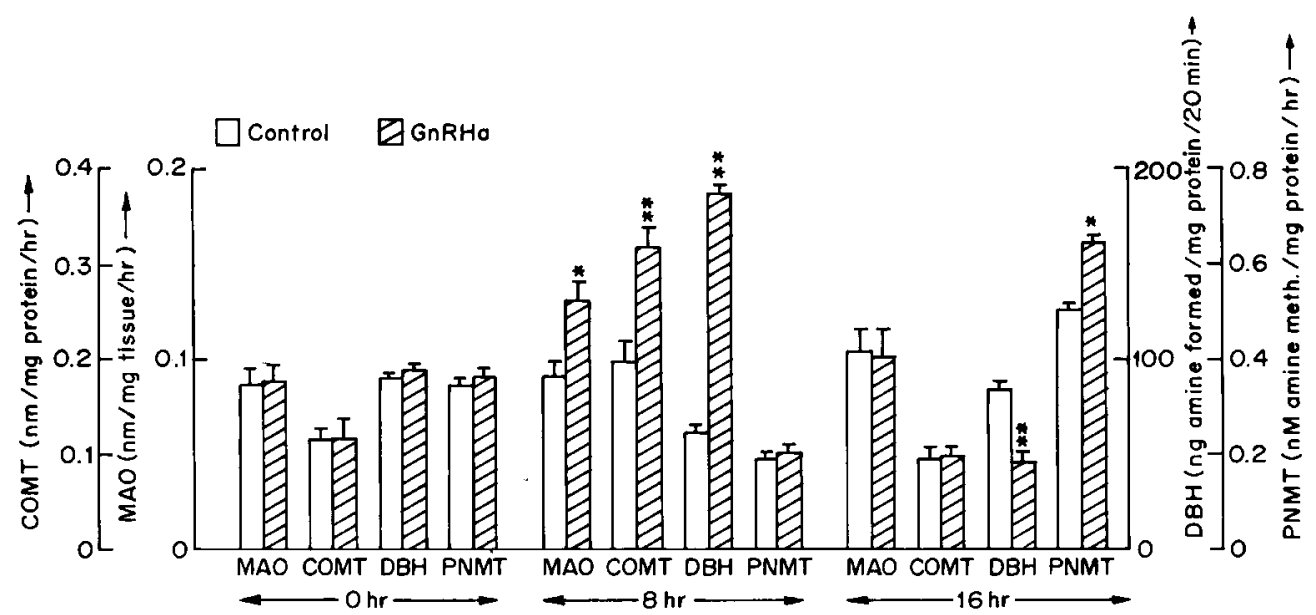

Figure 4 Periovulatory effects of a single injection of GnRHa on hypothalamic MAO, COMT, DBH and PNMT activities in the catfish Heteropneustes fossilis (means \pm S.E.M.; $n=5$ ). Comparisons with respective vehicle control groups: ${ }^{*} P<0 \cdot 05,{ }^{* *} P<0 \cdot 001$; Student's $t$-test.

similar to those observed in the hypothalamus (in teleosts the hypothalamic monoamine neurons innervate the pituitary directly (Peter \& Fryer 1983)). The DA content was still low at $16 \mathrm{~h}$, unlike in the hypothalamus, and may explain the high level of GTH II at $16 \mathrm{~h}$. It is interesting to note that adrenaline was not detected in the pituitary and may not have any hypophysiotrophic role. The increased level of adrenaline at $16 \mathrm{~h}$ in the hypothalamus may be part of a mechanism to remove the excess NA to restore GTH II secretion to control levels.

The factors involved in the changes in hypothalamic and pituitary monoamine during the GnRHa treatment need to be considered next. The changes in plasma levels of gonadal steroids give some indications. It is evident from the data that there was a clear shift in steroid metabolism during the periovulatory period. These changes are (1) significant decrease in plasma $\mathrm{OE}_{2}$ at $2,4,8$ and $12 \mathrm{~h}$ with the ebb at $8 \mathrm{~h}$ and its significant elevation after stripping of eggs at 16 and $48 \mathrm{~h}$ and (2) $\mathrm{OE}_{2}$ maintained an inverse relation with the testosterone levels. The rate of aromatization may be altered to maintain this inverse relationship. The decreased response of $\mathrm{OE}_{2}$ during the periovulatory period was similar to that reported in salmonids (Fostier \& Jalabert 1982, Scott et al. 1983, Van der Kraak et al. 1984, Kime \& Dolben 1985, LevaviZermonsky \& Yaron 1986, Liley et al. 1986), bitterling (Shimizu et al. 1985) and white sucker (Scott et al. 1984), which exerts a negative feedback effect on brain and pituitary GnRH activity during induction of spawning (Breton et al. 1986). In rainbow trout, during the periovulatory period coinciding with the low titre of $\mathrm{OE}_{2}$, a decrease in both hypothalamic and pituitary DA turnover and an increase in hypothalamic 5-HT turnover have been reported (Saligaut et al. 1992). It was further reported that oestrogen receptors were expressed in a subset of tyrosine hydroxylase-positive (dopaminergic) neurons of the preoptic region, thus participating directly in DA inhibition of GTH II release (Linard et al. 1996). Thus the fall in $\mathrm{OE}_{2}$ removes the DA inhibition, allowing the preovulatory surge of GTH II. We have already demonstrated in the catfish that $\mathrm{OE}_{2}$ mediates the negative feedback control of GTH II release by acting differentially on hypothalamic monoamine activity: DA activity is inhibited and NA and 5-HT activities enhanced, and vice versa (Senthilkumaran \& Joy 1994, 1995). Such inverse relationships of DA with NA and 5-HT underlying GTH II secretion have been reported in the catfish under natural conditions (seasonal data) or after ovariectomy and replacement with various doses of $\mathrm{OE}_{2}$ (references as above). In 3-week ovariectomized catfish (prespawning phase), $\mathrm{OE}_{2}$ produced a steady and significant increase in DA content and turnover and significant decrease in NA and adrenaline contents and turnover in a dose-related manner; plasma GTH II level declined correspondingly (Senthilkumaran \& Joy 1995). Therefore it is reasonable to assume that, during the periovulatory period, the low titre of $\mathrm{OE}_{2}$ altered the monoaminergic activity differentially to stimulate endogenous GnRH secretion, which together with the exogenously administered $\mathrm{GnRHa}$ produced the sustained and significant increase in GTH II release for about $16 \mathrm{~h}$. This endogenous inhibition of DA may explain the prolonged ability of GnRHa to induce ovulation without using a DA antagonist. The participation of other sex steroids that showed elevated titres in the activation of the GTH II regulatory mechanism is not clear. Dulka et al. (1992) have reported that $17 \alpha, 20 \beta-\mathrm{P}$ which acts as a pheromone in goldfish, lowered DA turnover in the pituitary, favouring GTH II release. However, 
in the catfish, $17 \alpha, 20 \beta-\mathrm{P}$ is a poor odorant (K P Joy, B Tharakan \& S B Deshpande, unpublished observations).

During the GnRHa-induced ovulation of the catfish, plasma levels of both cortisol and progesterone exhibited significant rises, with the cortisol pattern following closely the GTH II levels. The periovulatory rise in the cortisol level is probably not due to stress since the control fish were handled similarly at all time points. A periovulatory rise in cortisol has also been demonstrated in goldfish (Cook et al. 1980), brown trout (Pickering \& Christie 1981), carp (Kime \& Dolben 1985) and white sucker (Scott et al. 1984). The elevated cortisol level has been ascribed to stimulation of interrenal activity by GTH (Sundararaj \& Goswami 1977). Barry et al. (1995) have reported that $17 \alpha, 20 \beta-\mathrm{P}$ could be a physiological regulator of cortisol secretion in periovulatory salmonids. However, the present data on changes in monoamine metabolism suggest a central effect on adrenocorticotrophin secretion to stimulate cortisol secretion. Unlike the GTH II- and cortisol-release patterns, a prominent 'surge' of progesterone secretion was not evident. This may be due to its rapid conversion into $17 \alpha$-hydroxyprogesterone and $17 \alpha, 20 \beta-\mathrm{P}$; the latter steroids were not monitored in this study because of technical constraints. 17 $2,20 \beta-\mathrm{P}$ is considered to be the most active maturation-inducing hormone in several teleosts, including the catfish (Sundararaj et al. 1985, Nagahama 1991).

In conclusion, during the GnRHa-induced ovulation of the catfish, the changes in the steroid milieu, especially the decreased $\mathrm{OE}_{2}$ level, caused significant changes in hypothalamic and pituitary monoamine contents, modulating GnRH-induced GTH II release for a prolonged period.

\section{Acknowledgements}

This work was supported by a research grant from the CSIR, New Delhi to K P J. The gifts of GTH II and its antibody from Professor $\mathrm{HJ}$ Th Goos, $\mathrm{OE}_{2}$ antiserum from Professor G D Niswender, purified COMT from Professor $\mathrm{J}$ C Porter and cortisol EIA kit and testosterone antiserum from Dr G L Kumari are gratefully acknowledged. We thank Dr J K Datta for his help with the iodination of GTH II.

\section{References}

Abraham GE 1974 Radioimmunoassay of steroids in biological materials. Acta Endocrinologica 183 (Suppl. 75) 1-42.

Barry T, Riebe JR, Parrish J \& Malison J 1995 17 $\alpha, 20 \beta$ - dihydroxy4-pregnen-3-one stimulates cortisol production by rainbow trout interrenal tissue in vitro: mechanism of action. In Reproductive Physiology of Fish, pp 325. Eds FW Goetz \& P Thomas. Austin: Fish Symposium 95.

Ben-Jonathan N \& Porter JC 1976 A sensitive radioenzymatic assay for dopamine, norepinephrine, and epinephrine in plasma and tissue. Endocrinology 98 1497-1507.
Breton B, Motin A, Billard R, Kah O, Geoffre S \& Precigoux G 1986 Immunoreactive gonadotropin-releasing hormone-like material in the brain and the pituitary gland during the periovulatory period in the brown trout (Salmo trutta L.): relationships with the plasma and pituitary gonadotropin. General and Comparative Endocrinology 61 109-119.

Chang JP \& Peter RE 1983 Effects of pimozide and des Gly ${ }^{10}$, $\left[\mathrm{D}-\mathrm{Ala}^{6}\right]$-luteinizing hormone-releasing hormone ethylamide on serum gonadotropin concentrations, germinal vesicle migration, and ovulation in female goldfish, Carassius auratus. General and Comparative Endocrinology 52 30-37.

Cook AF, Stacey, NE \& Peter RE 1980 Periovulatory changes in serum cortisol levels in the goldfish Carassius auratus. General and Comparative Endocrinology 40 507-510.

Coyle JT \& Axelrod J 1972 Dopamine- $\beta$-hydroxylase in the rat brain: developmental characteristics. Journal of Neurochemistry 19 449-459.

Dulka JG, Sloley BD, Stacey NE \& Peter RE 1992 A reduction in pituitary dopamine turnover is associated with sex pheromoneinduced gonadotropin secretion in male goldfish. General and Comparative Endocrinology 86 496-505.

Fostier A \& Jalabert B 1982 Physiological basis of practical means to induce ovulation in fish. In Proceedings of the International Symposium on Reproductive Physiology of Fish, pp 164-173. Eds CJJ Richter \& HJTh Goos. Wageningen: Pudoc.

Goos HJTh, de Leeuw R, Burzawa-Gerard E, Terlou M \& Richter CJJ 1986 Purification of gonadotropic hormone from the pituitary of the African catfish, Clarias gariepinus (Burchell), and the development of a homologous radioimmunoassay. General and Comparative Endocrinology 63 162-170.

Goos HJTh, Joy KP, de Leeuw R, Van Oordt PGWJ, Van Delft AML \& Gielen JTh 1987 The effect of luteinizing hormone releasing hormone analogue (LHRHa) in combination with different drugs with anti-dopamine and anti-serotinin properties on gonadotropin release and ovulation in the African catfish, Clarias gariepinus. Aquaculture 63 143-156.

Khan IA \& Thomas P 1992 Stimulatory effects of serotonin on maturational GTH release in the Atlantic croaker, Micropogonias undulatus. General and Comparative Endocrinology 88 358-396.

Kime DE \& Dolben IP 1985 Hormonal changes during induced ovulation of the carp, Cyprinus carpio. General and Comparative Endocrinology 58 137-149.

Koide Y, Noso T, Schouten G, Peute J, Zandbergen MA, Bogerd J, Schulz RW, Kawauchi H \& Goos HJTh 1992 Maturational gonadotropin from the African catfish, Clarias gariepinus: Purification, characterization, localization and biological activity. General and Comparative Endocrinology 87 327-341.

de Leeuw R, Resink W, Rooyakkers EJM \& Goos HJTh 1985 Pimozide modulates the luteinizing hormone-releasing hormone effect on gonadotropin release in the African catfish, Clarias lazera. General and Comparative Endocrinology 58 120-127.

de Leeuw R, Goos HJTh \& Van Oordt PGWJ 1987 The regulation of gonadotropin release by neurohormones and gonadal steroids in the African catfish, Clarias gariepinus. Aquaculture 63 43-58.

Levavi-Zermonsky B \& Yaron Z 1986 Changes in gonadotropin and ovarian steroids associated with oocyte maturation during spawning induction in the carp. General and Comparative Endocrinology 62 89-98.

Liley NR, Fostier A, Breton B \& Tan ESP 1986 Endocrine changes associated with spawning behavior and social stimuli in a wild population of rainbow trout (Salmo gairdneri). II. Females. General and Comparative Endocrinology 62 157-167.

Linard B, Anglade I, Corio M, Navas JM, Pakdel F, Saligaut C \& Kah O 1996 Estrogen receptors are expressed in a subset of tyrosine hydroxylase-positive neurons of the anterior preoptic region in the rainbow trout. Neuroendocrinology 63 156-165.

Manickam P \& Joy KP 1989 Induction of maturation and ovulation by pimozide-LHRH analogue treatment and resulting high quality egg 
production in the Asian catfish, Clarias batrachus L. Aquaculture $\mathbf{8 3}$ 193-199.

Mattox VR, Litwiler RD \& Nelson AN 1979 A comparison of procedures for attaching steroidal glucosiduronic acid to bovine serum albumin. Journal of Steroid Biochemistry 10 167-172.

Nagahama Y 1991 Endocrine regulation of gametogenesis in fish. Bulletin of the Institute of Zoology, Academia Sinica Monograph 16 139-172.

Parvez H \& Parvez S 1973 Microradioisotopic determination of enzymes, catechol O-methyltransferase, phenylethanol-amine $\mathrm{N}$-methyltransferase and monoamine oxidase in a single concentration of brain homogenate. Clinica Chimica Acta 40 85-90.

Peter RE \& Fryer JN 1983 Endocrine functions of the hypothalamus of actinopterygians. In Fish Neurobiology, Higher Brain Areas and Functions, vol 2, pp 165-201. Eds RE Davis \& RG Northcutt. Ann Arbor: University of Michigan Press.

Peter RE, Trudeau VL \& Sloley BD 1991 Brain regulation of reproduction in teleosts. Bulletin of the Institute of Zoology, Academia Sinica Monograph 16 89-118.

Pickering AD \& Christie P 1981 Changes in the concentrations of plasma cortisol and thyroxine during sexual maturation of the hatchery-reared brown trout, Salmo trutta L. General Comparative and Endocrinology 44 487-496.

Saligaut C, Salbert G, Bailhache T, Bennani S \& Jego P 1992 Serotonin and dopamine turnover in the female rainbow trout (Oncorhynchus mykiss) brain and pituitary: changes during the annual reproductive cycle. General and Comparative Endocrinology 85 261-268.

Scott AP, Sumpter JP \& Handiman PA 1983 Hormone changes during ovulation in the rainbow trout (Salmo gairdneri Richardson). General and Comparative Endocrinology 49 128-134.

Scott AP, Mackenzie DS \& Stacey NE 1984 Endocrine changes during natural spawning in the white sucker, Catostomus commersoni. II. Steroid hormones. General and Comparative Endocrinology 56 349-359.

Senthilkumaran B \& Joy KP 1993 Annual variations in hypothalamic serotonin and monoamine oxidase in the catfish Heteropneustes fossilis with a note on brain regional differences of day-night variations in gonadal preparation phase. General and Comparative Endocrinology 90 372-382.

Senthilkumaran B \& Joy KP 1994 Effects of ovariectomy and oestradiol replacement on hypothalamic serotonergic and monoamine oxidase activity in the catfish, Heteropneustes fossilis: a study correlating plasma oestradiol and gonadotrophin levels. Journal of Endocrinology 142 193-203.

Senthilkumaran B \& Joy KP 1995 Changes in hypothalamic catecholamines, dopamine- $\beta$-hydroxylase, and phenylethanolamine$\mathrm{N}$-methyltransferase in the catfish Heteropneustes fossilis in relation to season, raised photoperiod and temperature, ovariectomy, and estradiol-17 $\beta$ replacement. General and Comparative Endocrinology 97 $121-134$.
Senthilkumaran B \& Joy KP 1996 Effects of administration of some monoamine-synthesis blockers and precursors on ovariectomyinduced rise in plasma gonadotropin II in the catfish Heteropneustes fossilis. General and Comparative Endocrinology 101 220-226.

Shimizu A, Aida K \& Hanyu T 1985 Endocrine profiles during short reproductive cycle of an autumn spawning bitterling, Acheilognathus rhombea. General and Comparative Endocrinology 60 361-371.

Shrivastav TG, Kumari GL \& Rao PN 1988 Enzyme immunoassay of cortisol in human plasma using penicillinase as label. Clinica Chimica Acta 174 83-92.

Snyder SH, Axelrod J \& Zweig M 1965 A sensitive and specific fluorescence assay for tissue serotonin. Biochemistry and Pharmacology 14 831-835.

Somoza GM \& Peter RE 1991 Effects of serotonin on GTH and growth hormone release from in vitro perifused goldfish pituitary fragments. General and Comparative Endocrinology 82 103-110.

Sundararaj BI \& Goswami SV 1977 Hormonal regulation of in vivo and in vitro oocyte maturation in the catfish, Heteropneustes fossilis (Bloch). General and Comparative Endocrinology 32 17-28.

Sundararaj BI, Goswami SV \& Lamba VJ 1985 Oocyte maturation in teleost fishes. In Current Trends in Comparative Endocrinology, pp 369-372. Eds B Lofts \& WN Holmes. Hong Kong: Hong Kong University.

Tharakan B \& Joy KP 1996 Effects of mammalian gonadotropinreleasing hormone analogue, pimozide, and the combination on plasma gonadotropin levels in different seasons and induction of ovulation in female catfish. Journal of Fish Biology 48 623-632.

Trudeau VL \& Peter RE 1995 Functional interaction between neuroendocrine systems regulating GTH-II release. In Reproductive Physiology of Fish, pp 44-48. Eds FW Goetz \& P Thomas. Austin: Fish Symposium 95.

Van der Kraak G, Lin H, Donaldson EM \& Hunter GA 1983 Effects of LH-RH and des-Gly ${ }^{10}\left[\mathrm{D}-\mathrm{Ala}^{6}\right]$ LH-RH ethylamide on plasma gonadotropin levels and oocyte maturation in adult female coho salmon (Oncorhynchus kisutch). General and Comparative Endocrinology 49 470-476.

Van Der Kraak G, Dye HM \& Donaldson EM 1984 Effects of LHRH and des-Gly ${ }^{10}\left[\mathrm{D}-\mathrm{Ala}^{6}\right]-\mathrm{LH}-\mathrm{RH}$-ethylamide on plasma sex steroid profiles in adult female coho salmon (Oncorhynchus kisutch). General and Comparative Endocrinology 55 36-45.

Yaron Z 1995 Endocrine control of gametogenesis and spawning induction in the carps. Aquaculture 129 49-73.

Yu KL \& Peter RE 1992 Adrenergic and dopaminergic regulation of brain gonadotropin-releasing hormone release from goldfish preoptic-anterior hypothalamus and pituitary in vitro. General and Comparative Endocrinology 85 138-146.

Received 30 April 1997

Revised manuscript received 15 July 1997

Accepted 26 August 1997 